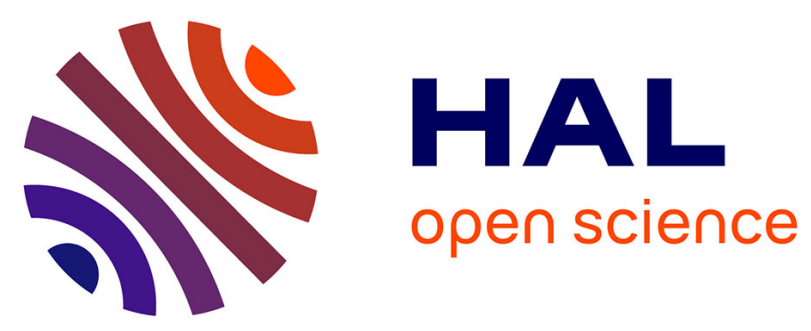

\title{
Cytotoxicity of sesquiterpenes ferulenol and coladin on liver FAO and B16F1 melanoma cells
}

Ben Mhidi, Oum El Bouaghi, Malika Boulmeltout, Amar Zellagui, Lamia Benguedouar, Gillian Barratt, Mesbah Lahouel

\section{- To cite this version:}

Ben Mhidi, Oum El Bouaghi, Malika Boulmeltout, Amar Zellagui, Lamia Benguedouar, et al.. Cytotoxicity of sesquiterpenes ferulenol and coladin on liver FAO and B16F1 melanoma cells. Pharmacognosy Magazine, 2018, 14 (56), pp.333. 10.4103/pm.pm_611_17. hal-02370644

\section{HAL Id: hal-02370644 \\ https://hal.science/hal-02370644}

Submitted on 19 Nov 2019

HAL is a multi-disciplinary open access archive for the deposit and dissemination of scientific research documents, whether they are published or not. The documents may come from teaching and research institutions in France or abroad, or from public or private research centers.
L'archive ouverte pluridisciplinaire $\mathbf{H A L}$, est destinée au dépôt et à la diffusion de documents scientifiques de niveau recherche, publiés ou non, émanant des établissements d'enseignement et de recherche français ou étrangers, des laboratoires publics ou privés. 
ORIGINAL ARTICLE

Year : 2018 | Volume : 14 | Issue : 56 | Page : 333--337

\title{
Cytotoxicity of sesquiterpenes ferulenol and coladin on liver FAO and B16F1 melanoma cells
}

Malika Boulmeltout ${ }^{1}$, Amar Zellagui ${ }^{2}$, Lamia Benguedouar ${ }^{1}$, Gillian Barratt ${ }^{3}$, Mesbah Lahouel ${ }^{1}$,

${ }_{1}^{1}$ Department of Natural and Life Sciences, Laboratory of Molecular Toxicology, Faculty of Sciences, University of Jijel, Jijel, Algeria

${ }^{2}$ Laboratory of Biomolecules and Plant Breeding, Faculty of Sciences SNV, University of Larbi Ben Mhidi, Oum El Bouaghi, Algeria

${ }^{3}$ CNRS, Faculty of Pharmacy, University of Paris-Sud XI, Chatenay-Malabry, France

Correspondence Address:

Mesbah Lahouel

Laboratory of Molecular Toxicology, Faculty of Sciences, University of Jijel, 18000, Jijel

Algeria

\begin{abstract}
Background: Ferula vesceritensis is an indigenous plant of Algerian Sahara riche in sesquiterpene coumarins. Objective: In this study, we investigated the biological activity of sesquiterpene coumarins; coladin, ferulenol, and lapiferin (10_-acetoxy-6_-angeloyloxy-8_,9_-epoxy-trans-caxotan-4_-ol) isolated for the first time from the $\mathrm{crude}_{-}$extract $\mathrm{CH}_{2} \mathrm{Cl}_{2}-\mathrm{MeOH}$ (1:1) of the roots of $F$. vesceritensis Coss. et Dur. Materials and Methods: Structures of coladin, ferulenol, and lapiferin were determined by extensive nuclear magnetic resonance (NMR) analyses, including $1 \mathrm{D}-\left({ }^{1} \mathrm{H}\right.$ and ${ }^{13} \mathrm{C}$ ) and 2D-NMR experiments (correlation spectroscopy, heteronuclear single-quantum coherence, heteronuclear multiple bond correlation (HMBC), and nuclear overhauser effect spectroscopy) as well as high-resolution electron ionization mass spectra and mass spectroscopy analyses. Results: Tested on mouse B16F1 melanoma cells, ferulenol, coladin, and lapiferin exhibited a significant decrease in cell proliferation and a decrease of mitochondrial dehydrogenase activity evaluated on living FAO cells and B16F1 melanoma cells with the WST-1 throughout an apoptotic pathway. They displayed pro-apoptotic effects observed by a decrease in mitochondrial membrane potential and the mitochondrial respiratory rate on isolated liver mitochondria in a dose-dependent manner. Conclusion: Our results highlight the importance of the sesquiterpene coumarins extracted from F. vesceritensis as new biologically active natural products against cancer cells. Abbreviations used: FAO: Hepatoma cell line; B16F1: Pulmonary metastasis melanoma cell line.
\end{abstract}

How to cite this article:

Boulmeltout M, Zellagui A, Benguedouar L, Barratt G, Lahouel M. Cytotoxicity of sesquiterpenes ferulenol and coladin on liver FAO and B16F1 melanoma cells.Phcog Mag 2018;14:333337

How to cite this URL:

Boulmeltout M, Zellagui A, Benguedouar L, Barratt G, Lahouel M. Cytotoxicity of sesquiterpenes ferulenol and coladin on liver FAO and B16F1 melanoma cells. Phcog Mag [serial online] 2018 [cited 2019 Nov 22 ]; 14:333-337

Available from: http://www.phcog.com/text.asp?2018/14/56/333/238895

\section{Full Text}

[INLINE:1]

SUMMARY

Sesquiterpenes Ferulenol and Coladin decrease FAO and B16F1 Melanoma Cells proliferation throughout an apoptotic pathway.

Introduction

The exclusively old-world genus Ferula, belonging to the family Apiaceae, known as a good source of biologically active compounds, comprises about 170 species widely distributed throughout the Mediterranean area and Central Asia.[1] These plants are often used as spices and in the preparation of local drugs. The resins are reported to be used for stomach disorders such as a febrifuge and carminative agent.[2] Some species are used in traditional medicine for the treatment of skin infections[3] and hysteria.[2] Previous work dealing with members of this genus revealed that the main constituents are sesquiterpenes and sesquiterpene coumarins. More than seventy species have been chemically studied leading to the fact that germacranes, humulanes, carotanes, himachalanes, and guaianes represent the main sesquiterpene constituents of the genus.[3],[4],[5],[6],[7],[8],[9],[10] Ferula spp. are also known for their toxicity and pharmacology. The species Ferula asafoetida has been reported to exhibit anticarcinogenic properties and afford protection against free radical-mediated diseases[11],[12] and exhibit anti-leishmanial activity against promastigotes.[13] Daucane esters from Ferula communis and Ferula arrigonii showed antiproliferative activity on human colon cancer cell lines[14] and calcium iontophoretic and apoptotic effects in the human Jurkat T-cell line.[15]

Ferula vesceritensis (Batt.), which has the synonym Ferula tingitana L. var, is an endemic plant to Algeria and Libya, where it is extensively used in traditional medicine to treat cancer and inflammatory diseases.[16],[17] F. vesceritensis is indigenous to Algerian Sahara. According to ethno botanical investigation, however, its fruit decoction is used in folk medicine to treat headaches, fever, and throat infections, while the livestock avoid grazing it.[18]

In our recent communication, we reported the isolation and structure elucidation of two new sesquiterpene coumarins[19],[20] from a methylene chloride extract of $F$. vesceritensis. It is evident from the literature and previous investigations that the genus Ferula possesses high biological activities,[19] which prompts us to study the anticancer activity for the major isolated compound, lapiferin, from $\mathrm{F}$. vesceritensis, using different extraction methods.

On our continued investigation carried out for the chemical and pharmacological studies on the roots of F. vesceritensis,[19],[20],[21],[22] we have reported the specific anticancer activity of the isolated compounds. A sesquiterpene coumarins; Ferulenol, coladin and carotene sesquiterpene designed lapiferin (10_-acetoxy-6_-angeloyloxy-8_, 9_-epoxy-trans-caxotan-4_-ol) for the first time from F. vesceritensis as a new natural source against human cancer cells [Figure 1].\{Figure 1\}

\section{Materials and Methods}


Roots of $\mathrm{F}$. vesceritensis $(1.5 \mathrm{~kg})$ were crushed and extracted with $\mathrm{CH} 2 \mathrm{Cl} 2-\mathrm{MeOH}(1: 1)$ at room temperature. The extract was concentrated in vacuo to yield $30 \mathrm{~g}$ of oily residue. The residue was fractionated on a silica gel column Sephadex $\mathrm{LH} 420$ eluted with hexane, followed by a gradient of hexane- $\mathrm{CH} 2 \mathrm{Cl} 2 \mathrm{up}$ to $100 \% \mathrm{CH} 2 \mathrm{Cl} 2$ and $\mathrm{CH} 2 \mathrm{Cl} 2-\mathrm{MeOH}$ up to $15 \%$ $\mathrm{MeOH}$

After analyses on thin-layer chromatography (TLC) using vanillin as a revelator, similar fractions were gathered and subjected to further separation on silica gel and Sephadex LH-20 columns. The main fractions 2,3 , and 4 (hexane- $\mathrm{CH} 2 \mathrm{Cl} 2[3: 1]$, [1:1], [1:3]) were considered owing to their terpenoid content. The main fractions 2 and 3 were gathered and subjected to further fractionation on silica gel to afford three fractions.

Fraction 1 was subjected to purification using Sephadex LH-20 $(2 \mathrm{~cm} \times 40 \mathrm{~cm})$ and eluted with n-hexane-CH2 $\mathrm{Cl} 2(7: 4)$ to afford three more subfractions which were in turn subjected to further purifications as follows:

Subfraction 1 was further purified through Sephadex LH-20 $(1 \mathrm{~cm} \times 30 \mathrm{~cm})$ and eluting with n-hexane-CH2 $\mathrm{Cl} 2-\mathrm{MeOH}(7: 4: 0.25)$ and was then purified by TLC developed in hexanediethyl ether (1:2) on a 0.2-mm aluminum sheet silica gel 60 F254 to afford compound LK1 (70 mg). Subfractions 2 and 3 were purified through silica gel to yield other compounds.

Fraction 2 was further purified by silica gel CC $(2 \times 40 \mathrm{~cm})$ eluted with hexane-EtOAc $(4: 1)$, and then separated by TLC to afford 6 LK8 $(5 \mathrm{mg})$. Fraction 3 was double purified through Sephadex LH-20 and eluted with n-hexane-CH2 Cl2-MeOH $(7: 4: 0.25)(1 \mathrm{~cm} \times 30 \mathrm{~cm})$ to afford compound $7 \mathrm{lk} 51(55 \mathrm{mg})$.

The structure of the three compounds was confirmed by $1 \mathrm{H}$ nuclear magnetic resonance spectrum $(250 \mathrm{MHz}$, $\mathrm{CDCl} 3)$ and high-resolution chemical ionization mass spectrum analysis. Ferulenol LK1 was in agreement with the molecular formula (C24H30O3) which was previously reported from Ferula species[4],[23],[24] and F. vesceritensis roots[20] Coladin LK 8 isolated from F. vesceritensis roots,[19] Lapiferin LK 51.[22],[25] from F. vesceritensis roots.

Biological assays

Isolation of rat liver mitochondria and measurement of mitochondrial swelling

Rat liver mitochondria were isolated as described previously.[26] Liver samples were placed in medium containing $250 \mathrm{mM}$ sucrose, $10 \mathrm{mM}$ Tris, and $1 \mathrm{mM}$ of the chelator ethylenediaminetetraacetic acid, with $\mathrm{pH} 7.2$ at $4^{\circ} \mathrm{C}$ and homogenized on ice using a Teflon $\circledast$ Potter homogenizer (Prolabo, France). After differential centrifugation of the homogenate, we obtain a final mitochondrial pellet containing approximately $80 \mathrm{mg}$ protein/ml. The protein content was determined by the method described by Elimadi et al.[27]

Mitochondrial swelling was assessed by measuring the decrease in absorbance at $520 \mathrm{~nm}$ using a Jasko model V-530 spectrophotometer from Europe s.r.I via confalonieri 25,22060 , Cremella (Co) Italy at a suspension of energized mitochondria according to Nazari and Iranshah and Suzuki et al.[28],[29]

\section{Cell cultures and cytotoxicity tests}

B16F1 cells, a metastatic subline of B16 murine melanoma pulmonary cells (d-Dr M Gregoire, INSERM U419, Nantes, France) were cultivated in RPMI 1640 medium, supplemented with $5 \%$ fetal calf serum (FCS) in 25-cm2 flasks (Nunclon, VWR Int, Strasbourg, France) at a humid atmosphere containing $5 \%$ CO2. UACC-903 cells, a melanoma cell line (Dr J Trent, Phoenix, Ariz), were cultivated in DMEM medium containing $4.5 \mathrm{~g} / \mathrm{l}$ glucose, supplemented with $5 \% \mathrm{FCS}$ in $25 \mathrm{~cm} 2$ flasks (Nunclon) in a moist atmosphere containing $5 \%$ CO2. B16F1 cells $\left(10,000\right.$ cells per well in 96-well plates) were seeded in growth medium for $24 \mathrm{~h}$ and cultured at $37^{\circ} \mathrm{C}$ and $5 \%$ CO2. Ferulenol at concentrations of $10 \mu \mathrm{M}$ in $0.005 \%$ ethanol was added to the cells for $30 \mathrm{~min}$, at 2 and $4 \mathrm{~h}$. Cell viability was determined by the WST-1 test using a Dynatech MR 4000 plate reader. All measurements were carried out in triplicate. The WST-1 test is based on the cleavage of tetrazolium salts to formazan by cellular enzymes. An expansion in the number of viable cells resulted in an increase in the overall activity of mitochondrial dehydrogenases in the sample. This augmentation in enzyme activity has led to an increase in the amount of formazan dye formed, which has directly correlated to the number of metabolically active cells in the culture.

B16F1 cells were a generous gift from Dr. F Antonocelli (Unité Mixte de Recherche 6198, Institut Fédératif de Recherche 53 Biomolecules, Université de Reims Champagne-Ardenne, 51 rue Cognacq Jay, F-51095 Reims Cedex, France). They were grown in RPMI 1640 supplemented with 5\% fetal bovine serum (FBS) in 25-cm2 flasks (Nunclon, Dutscher, Brumath, France) at $37^{\circ} \mathrm{C}$ in a humid atmosphere $(5 \% \mathrm{CO} 2,95 \%$ air $)$.

FAO cells were obtained from rat hepatoma (Sigma Aldrich, France), a differentiated cell line derived from H4-11-E-C3 (ECACC catalog number 85061112). The cytotoxicity of ferulenol, lapiferin, and coladin was estimated by the (3-(4,5-dimethylthiazol-2-yl)-2,5-diphenyltetrazolium bromide) tetrazolium reduction (MTT) assay. Cells were incubated with increasing concentration of each compound and then exposed for $48 \mathrm{~h}$ in a $5 \% \mathrm{CO} 2$ incubator at $37^{\circ} \mathrm{C}$. After incubation, $20 \mu \mathrm{l} \mathrm{MTT}$ (Sigma) $(5 \mathrm{mg} / \mathrm{mL})$ solution was added in all wells, except in one well that served as blank, and incubated at $37^{\circ} \mathrm{C}$ for $4 \mathrm{~h}$. Finally, the medium was removed and formazan salt crystals were dissolved by addition of $200 \mu \mathrm{l}$ of dimethylsulfoxide (Biobasic Inc, France) to all wells. Plates were then analyzed in an ELISA plate reader (Labsystems multiskan RS-232C, Finland) at $570 \mathrm{~nm}$. Cell viability was defined relative to untreated control cells as follows:

Subculture

Split at 70\%-80\% confluency, approximately 1:3-1:6 (2-4 × 104 cells/cm2) trypsinize using $0.25 \%$ solution, with or without EDTA, at $37^{\circ} \mathrm{C}$ and $5 \%$ CO2

Culture medium

The culture medium included Coon's Modified Ham's F12 +2 mM L-Glutamine $+10 \%$ FBS or Kaighn's Modified Ham's F12 + 2 mM L-Glutamine +45 mg/L ascorbic acid +18 mg/L myoinositol $+10 \%$ FBS

\section{Results}

Ferulenol modulates mitochondrial swelling

We first studied the effect of ferulenol and coladin on mitochondrial swelling which is the consequence of an increase in membrane permeability. In another set of experiments, we exploited the protocol described by Gamal-Eldeen and Hegazy[20] who had induced PTP by means of the addition of an uncoupler to mitochondria that have accumulated Ca2+ load and became unable to induce PTP per se, this effect translates the fact that the pore could be opened by depolarization. Surprisingly, in these experimental conditions, ferulenol did not inhibit mitochondrial swelling; on the contrary, it was able to promote swelling when it was added instead of the well-known uncoupling agent carbonyl cyanide m-chlorophenylhydrazone (CCCP) [Figure 2] and [Figure 3]. This effect was concentration dependent and was inhibited by CsA confirming the involvement of PTP in the swelling process. However, this result was not at variance with the inhibitory effect observed in [Figure 2] and [Figure 3]. This could be explained by the fact that ferulenol could have prevented the matrix mitochondrial Ca2+ accumulation which was required for swelling in this model. As ferulenol did not show any effect on mitochondrial calcium flux (not shown), this raised the possibility that ferulenol might act as an uncoupling agent. Furthermore, ferulenol added at increasing concentrations along with CCCP to isolated rat liver has allowed mitochondrial membrane potential to reestablish.[19] However, the rate of hydrogen superoxide production was declined as a result.[19] This possibly has had a link with the mitochondrial antioxidant defense system that had possibly prevented the oxidant cascade reactions. \{Figure 2\}\{Figure 3$\}$

Anticancer effects of ferulenol, coladin, and lapiferin

Exploring the cytotoxic effect of lapiferin on cancer cell lines, B16F1 and FAO cells were treated with different doses of lapiferin, coladin, and ferulenol and submitted to MTT assay, a metabolic cytotoxicity assay. The experiment indicated that ferulenol and lapiferin exhibited a dose-dependent cytotoxic effect at concentrations of $50 \mu \mathrm{M}$ and higher as shown in [Figure 4]. All the results are significantly different from the control by the Student's t-test. Therefore, we can assure that the effects of ferulenol, coladin, and lapiferin were not due to the vehicle ( $P>0.05$, Student's two-tailed test). Moreover, the 24-h treatment with coladin of both B16F1 and FAO cells has reflected nearly similar effect in both kinds of cell lines as indicated in [Figure 5]. whereas the 24-h treatment with ferulenol of both B16F1 and FAO cells shown in [Figure 6] reflected that the cytotoxic effect of ferulenol was markedly pronounced in B16F1 in 


\section{Discussion}

In this study, we reported the isolation and structure elucidation of new sesquiterpene coumarin coladin, from an extract of $F$. vesceritensis, and showed that sesquiterpenes ferulenol, lapiferin, and coladin promoted efficient cytotoxic effects and anticancer activity. Extracts from different species of the genus Ferula have had various biomedical applications for many centuries, and biological features of this genus such as cytotoxicity and antibacterial activity have been attributed to sesquiterpene coumarins as reported by Nazari and Iranshah.[28]

The antitumor activity of ferulenol, lapiferin, and coladin exhibited a dose-dependent cytotoxic effect depending on their ability to inhibit tumor cell proliferation in vitro. Of these active compounds, ferulenol had a strong antitumor activity on both FAO hepatocyte cells and metastatic melanoma pulmonary cells, B16F1 cells. Many authors have reported the cytotoxicity of sesquiterpene compounds. Moreover, a significant selective cytotoxicity of sesquiterpene isolated from roots of Ferula against multidrug-resistant cancer cells (KB-C2) has been reported. [30] As far as the anticancer activity is concerned, lapiferin isolated from F. vesceritensis has reflected this anticancer activity against human breast cancer cells (MCF-7).[21]

Considering all the previously mentioned elements, we speculated that the antitumor activity of sesquiterpenes could be due to their ability to alter many signaling pathways including stimulation of necrosis and induction of apoptosis. As a consequence, ferulenol was able to induce mitochondrial swelling, which may have contributed to the induction of apoptotic process. Apoptosis is a natural process to regulate the cell death induced by an external signal or mediated by mitochondria. We have previously reported that ferulenol brought about the mitochondrial respiratory chain disturbance and overproduction of $\mathrm{H} 2 \mathrm{O} 2$ induction.[20],[23] These results were in accordance with earlier observations reported by Lamnaouer et al.[22] on the anticancer activity of lapiferin against MCF-7. The later authors have also reported that the cell death pathway induced by lapiferin in human breast cancer cells was rather due to apoptosis and not necrosis involving the enhancement of DNA fragmentation and activation of caspases. Other sesquiterpene coumarins have been reported to have acted through similar mechanisms.[29],[31]

\section{Conclusion}

We have demonstrated for the first time that $\mathrm{F}$. vesceritensis compounds coladin, ferulenol, and lapiferin have had anticancer activity on FAO hepatocytes and metastatic melanoma pulmonary B16F1 cell lines. This cytotoxic activity could be attributed to an induction of apoptosis that includes mitochondrial swelling and alteration of mitochondrial membrane potential due to the presence of the prenyl moiety.[28] Although F. vesceritensis is a good source of many promising compounds, it could potentially be a good therapeutic candidate to fight against cancer.

\section{Acknowledgements}

We gratefully thank Frank Antonicelli (Unité Mixte de Recherche 6198, Institut Fédératif de Recherche 53 Biomolecules, Université de Reims Champagne-Ardenne, 51 rue Cognacq Jay, F-51095 Reims Cedex, France) for the melanoma cells.

Financial support and sponsorship

Nil.

Conflicts of interest

There are no conflicts of interest.

\section{References}

Al-Ja'fari AH, Vila R, Freixa B, Tom

Phytochemistry 2011;72:1406-13.

Boulus L. Medicinal Plants of North Africa. Algonae, MI: Herman; 1883.

Appendino G, Spagliardi P, Cravotto G, Pocock V, Milligan S. Daucane phytoestrogens: A structure-activity study. J Nat Prod 2002;65:1612-5.

Murray RD. Coumarins. Nat Prod Rep 1989;6:591-624.

Gonzalez AG, Barrer JB. Chemistry and the sources of mono and bicyclic sesquiterpenes from Ferula species. Prog Chem Org Nat Prod 1995;64:1492.

Appendino G, Jakupovic J, Alloatti S, Ballero M. Daucane esters from Ferula arrigonii. Phytochemistry 1997;45:1639-43.

Kojima K, Isaka K, Ondognii P, Zevgeegiin O, Gombosurengyin P, Davgiin K, et al. Sesquiterpenoid derivatives from Ferula ferulaeoides [correction of ferulioides]. IV. Chem Pharm Bull (Tokyo) 2000;48:353-6.

Chen B, Teranishi R, Kawazoe K, Takaishian Y, Honda G. Sesquiterpenoids from Ferula kuhistanica. Phytochemistry 200;54:717-22.

Su BN, Takaishi Y, Honda G, Itoh M, Takeda Y, Kodzhimatov OK, et al. Sesquiterpene coumarins and related derivatives from Ferula pallida. J Nat Prod 2000;63:436-40.

Nagatsu A, Isaka K, Kojima K, Ondognii P, Zevgeegiin O, Gombosurengyin P, et al. New sesquiterpenes from Ferula ferulaeoides (Steud.) korovin. VI. Isolation and identification of three new dihydrofuro[2,3-b] chromones. Chem Pharm Bull (Tokyo) 2002;50:675-7.

El Razek MH, Ohta S, Hirata T. Terpenoid coumarins of the genus ferula. Heterocycles 2003:60:689-716.

Saleem M, Alam A, Sultana S. Asafoetida inhibits early events of carcinogenesis: A chemopreventive study. Life Sci 2001;68:1913-21.

Iranshahi M, Arfa P, Ramzani M, Jaafari MR, Sadeghian H. Sesquiterpene coumarins szowitsiana and in vitro anti-leishmanial activity of 7-prenyoxycoumarins against promastigotes. Phytochemistry 2007b; 68:554-6.

Poli F, Appendino G, Sacchetti G, Ballero M, Magr cancer cell lines. Phytother Res 2005;19:152-7. Biochem Pharmacol 2004:68:875-83. Ahmed AA, Hegazy ME, Zellagui A, Rhouati S, Mohamed TA, Sayed AA, et al. Ferulsinaic acid, a sesquiterpene coumarin with a rare carbon skeleton from Ferula species. Phytochemistry 2007;68:680-6.

Biophys Res Commun 2007;355:252-7.

Gamal-Eldeen AM, Hegazy ME. A crystal lapiferin derived from ferula vesceritensis induces apoptosis pathway in MCF-7 breast cancer cells. Nat Prod Res 2010;24:246-57.

Nadia BH, Wided K, Kheira B, Hassiba R, Lamia B, Rhouati

Antiapoptotic role of propolis. Acta Biol Hung 2009;60:385-98. Hofer O, Widhalm M, Greger H. Circ Monatsh Chem 1984;115:1207-13.

Rustin P, Chretien D, Bourgeron T, Gérard B, Rötig A, Saudubray JM, et al. Biochemical and molecular investigations in respiratory chain deficiencies. Clin Chim Acta 1994;228:35-51.

Lowry OH, Rosebrough NJ, Farr AL, Randall RJ. Protein measurement with the folin phenol reagent. J Biol Chem 1951;193:265-75.

Bernardi P, Colonna R, Costantini P, Eriksson O, Fontaine E, Ichas F, et al . The mitochondrial permeability transition. Biofactors 1998;8:273-81.

Elimadi A, Spena R, Settaf A, Le Louet H, Tillement JP, Morin D. Attenuation of liver normothermic ischemia4reperfusion injury by preservation of mitochondrial functions with S415176, a potent trimetazidine derivative. Biochem Pharmacol 2001;62:509-16.

Nazari ZE, Iranshah M. Biologically active sesquiterpene coumarins from Ferula species. Phytothr Res 2011;25:315-23. 
Gholami O, Jeddi-Tehrani M, Iranshahi M, Zarnani AH, Ziai SA. Umbelliprenin from ferula szowitsiana activates both intrinsic and extrinsic pathways of apoptosis in Jurkat T-CLL cell line. Iran J Pharm Res 2013;12:371-6.

Iranshahi M, Sahebkar A, Takasaki M, Konoshima T, Tokuda H. Cancer chemopreventive activity of the Prenylated coumarin, umbelliprenin, in vivo . Eur J Cancer Prev 2009;18:412-5. 